\title{
Double Reversing Z Plasty for Tracheastomal Stenosis After Total Laryngectomy
}

\author{
(1) Burak Karabulut, (으 Hakan Avcı
}

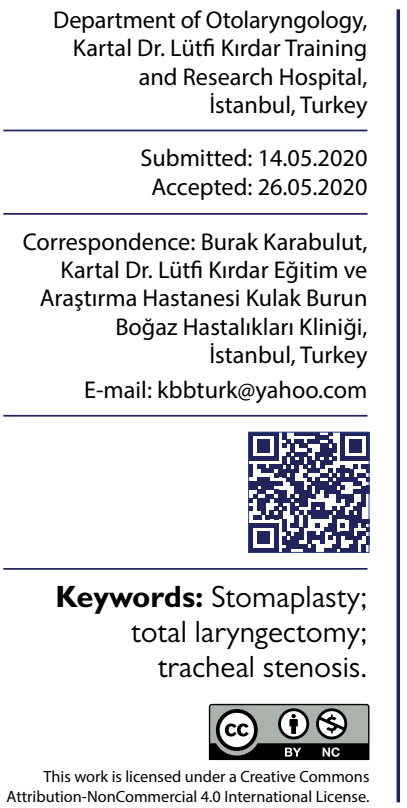

\author{
ABSTRACT \\ Objective: To assess the efficacy of double reversing $Z$ plasty technique for stomaplasty in \\ patients who had total laryngectomy.
}

Methods: This was retrospective chart review of 20 patients having tracheostomal widening procedure 'double reversing Z plasty at our department between August 2016 and October 2019. Widest length of the stoma was measured in $\mathrm{mm}$ for each patient preoperatively and at postoperative Ist month respectively. The results were compared.

Results: All 20 patients showed statistically significant widened tracheostoma without any complication. Mean diameter of the stoma was measured as $12 \pm 1.2 \mathrm{~mm}$ (range between $10-14$ ) and $21 \pm 1.3$ (range between 19-24) $\mathrm{mm}$ preoperatively and postoperatively, respectively. The difference was statistically meaningful $(p=0.01)$. 10 of patients $(50 \%)$ had voice prosthesis in previous total laryngectomy procedure and their phonatory protshesis functioned well after the surgery. All patients were discharged at postoperative day I. There was no need to wear laryngeal tube which shows successful amelioration of the disease in postoperative period.

Conclusion: Double reversing stomaplasty is an effective technique to manage tracheastomal stenosis in total laryngectomized patients without any complication specific to the technique.

\section{INTRODUCTION}

Total laryngectomy is commonly performed procedure since firstly described in 1873. [I] Since that time tracheal stenosis is a bothersome problem for both patients and surgeons. It has been showed that reduction of the tracheal lumen by $50 \%$ resulted in a $75 \%$ decrease in the cross-sectional surface area. ${ }^{[2]}$ This may not be a problem for patients with normal pulmonary capacity and reserve. However, the patients with chronic obstructive pulmonary disease will have trouble, specifically in exercise. The patients requiring positive airway pressure support may encounter hypoxia at rest if they have tracheal stenosis. Furthermore, tracheal stenosis may lead to increased secretions, incrustation through the tracheal lumen, mucosal infection including pneumonia, atelectasis and acute airway obstruction.

The patients having tracheal stenosis after total laryngectomy often require wearing an elongated laryngectomy tube to bypass the stenosis. The tube needs to be cleaned frequently due to maintenance of hygiene. The tube commonly causes the irritation of the tracheal mucosa and excessive cough production. Thus, some of patients find difficult to live with a tube in addition to a missed larynx.
The definition for tracheal stenosis after total laryngectomy is not fully clear. Langenbrunner and Chandler described it as requirement of tube at any time after operation. ${ }^{[3]}$ Yonker de"fined the tracheal stenosis as having symptoms preventing normal daily activities or necessitating the prolonged use of a laryngectomy tube. ${ }^{[4]}$ There are multiple factors that may have correlation with tracheal stenosis development after total laryngectomy. ${ }^{[5-7]}$ There are multiple surgical techniques defined for management. [8-11] One of the recent method for management of tracheal stenosis was described by Kim et al. ${ }^{\left[{ }^{1}\right]}$ as double reversing Z-plasty.

In our study we aimed to assess the effectiveness of the double reversing Z-plasty procedure in patients having tracheal stenosis following total laryngectomy.

\section{MATERIALS AND METHODS}

This was retrospective chart review of the patient who had stomaplasty surgery following total laryngectomy between August 2016 and October 2019. Twenty patients enrolled into the study. Tracheal stenosis was defined as laryngeal tube had to be worn even after 6 months of to- 
tal laryngectomy procedure. All the patients suited to the definition of the stenosis included into the study.

The widest diameter of the stoma was measured in $\mathrm{mm}$ preoperatively and at postoperative $2^{\text {nd }}$ month in all patients. The measurements were compared to assess the efficacy of the surgery. The efficacy also was evaluated as need to wear laryngeal tube after the stomaplasty.

\section{Surgical technique}

Double reversing Z-plasty technique was used for stomaplasty. ${ }^{\left[{ }^{\prime \prime}\right]}$ All procedures were performed under general anesthesia. Skin incision was placed at 4 and $80^{\prime}$ 'clock direction from the stoma each one $2 \mathrm{~cm}$ long and angled about $60^{\circ}$ from the stoma (Fig. Ia). After that double infrastomal incisions were made; one $3 \mathrm{~mm}$ apart from the inferior border of the stoma and the other with large $U$-shape, customized to need inferior the one above (Fig. la). After these incisions, each lateral skin flap was elevated, and subcutaneous fat and contractive scar tissue was removed along with the abundant skin (Fig. Ib). After proper exposure and mobilization of the trachea two vertical incisions of 3 tracheal rings were performed at 4 and $80^{\prime}$ clock direction of the trachea (Fig. Ic). The mobilized trachea was sutured to the newly created infrastomal area and both lateral skin flaps were sutured to the depths of the tracheal vertical incisions (double reversing Zplasty) (Fig. Id). The rest of the skin flap was sutured to the tracheal cartilage to cover it with semimattress sutures.

\section{Statistical analysis}

Analyses were performed with SPSS Statistics 22.0 (IBM Corp., Armonk, NY, USA). We used Wilcoxon test to compare the preoperative and postoperative diameters of the stoma measured in $\mathrm{mm}$. $\mathrm{P}$ value lower 0.05 accepted as significant data for this study.

\section{RESULTS}

I 8 (90\%) patients were male and 2 (10\%) of them were female. Mean diameter of the stoma was $12 \pm 1.2 \mathrm{~mm}$ (range between 10-14) and $21 \pm 1.3$ (range between 19-24) mm preoperatively and postoperatively, respectively. The difference was statistically meaningful $(p=0.01)$. All patients discharged at postoperative day I without any problems. There was no need to use laryngeal tube in any of the patients after stomaplasty surgery. 10 of the patients had voice prosthesis previously. None of those had problem about the voice prosthesis. Most of the patients had mild crusting problems at the along the stoma side in the first month. There was no revision surgery in any cases. All patients followed up at least for six months after stomaplasty surgery.
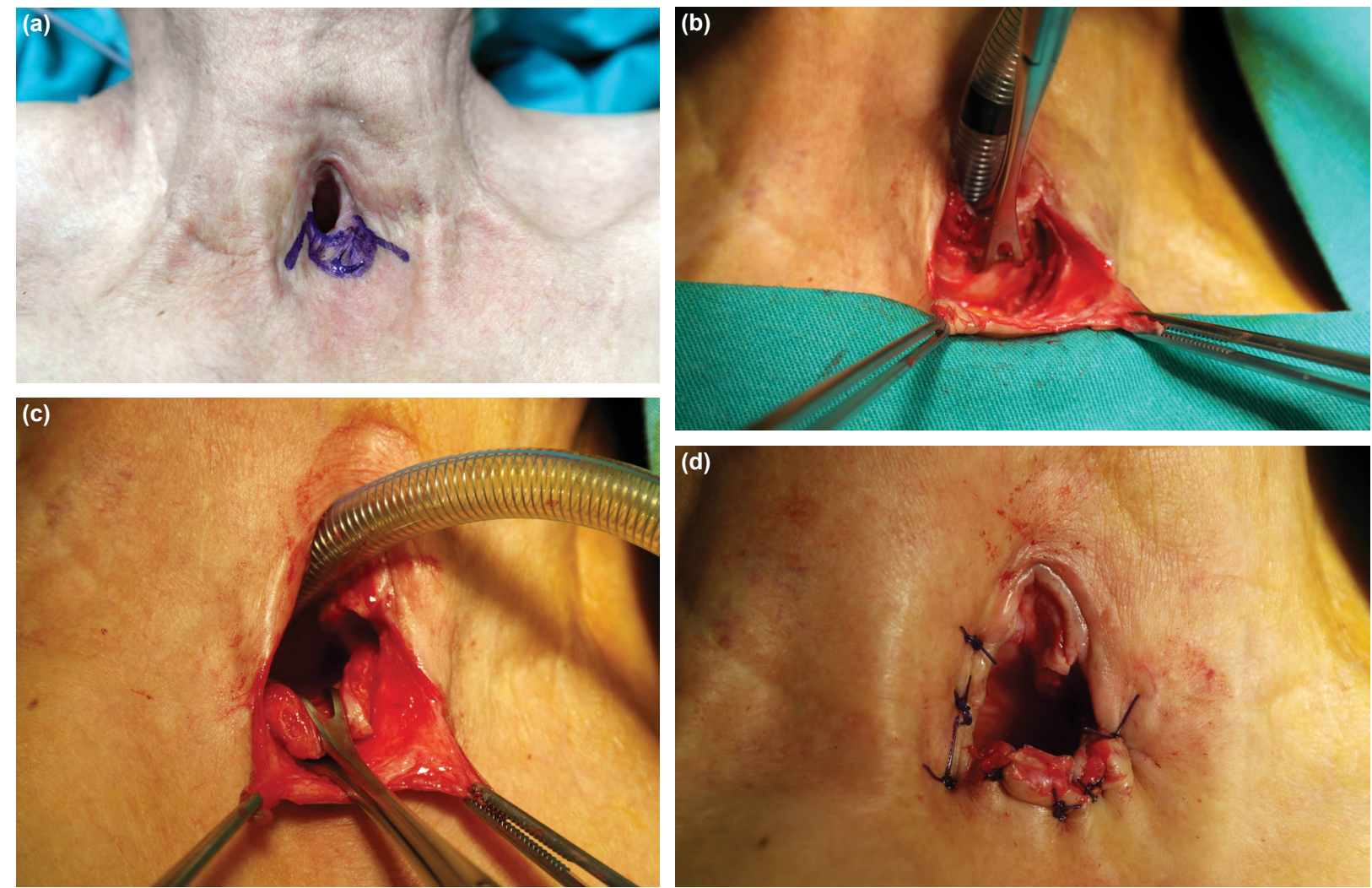

Figure 1. Sixty-five-year-old man had tracheal stenosis following total laryngectomy. (a) Shows skin incisions at 4 and $80{ }^{\circ}$ clock direction inferiorly from the stoma. Marked area will have double infrastomal incisions and this abundant skin will be removed. (b) Skin flaps elevated and trachea mobilized properly. (c) Vertical cuts through the 3 tracheal rings at 4 and $80{ }^{\circ}$ clock direction made. (d) Skin flaps sutured depth to the tracheal incisions which caused significant widening of the stoma. 


\section{DISCUSSION}

Tracheal stenosis is not an uncommon problem after total laryngectomy. There are ranging reports between $4 \%$ to $42 \%$ about the incidence of tracheal stenosis. ${ }^{[5-7]}$ Unfortunately, we did not have the tracheal stenosis incidence rate for this article due to nature of the study design. Radiotherapy has been reported as a cause of stenosis. [7] It may be due to impairment of wound healing or contracture scarring of the radiated area. In our study 4 of patients $(20 \%)$ had radiotherapy. Kuo and Wax reported that tracheal stenosis was significantly more in women. ${ }^{[6,7]}$ However, in our study 3 of patients (15\%) were women. This gender difference may be due to cross sectional area of the trachea. Nigam et al. ${ }^{[12]}$ showed that there was great difference in cross-sectional area of the trachea between the genders. There are also reports suggesting that pectoralis major myocutaneous flap reconstruction was not a significant factor for tracheal stenosis. None of our patients who had tracheal stenosis surgery had pectoralis major myocutaneous flap reconstruction for pharynx. So, our study also supports the literature.

Theoretically radical neck dissection would decrease the incidence of tracheal stenosis because of sternocleidomastoid muscle dissection during the procedure. However, the literature is against that ${ }^{[6,7,9]}$ None of our patients had radical neck dissection. We perform modified versions of radical neck dissection sparing the muscle in most of the cases. But it is a widely accepted method to divide the sternal head of the sternocleidomastoid muscle if it is prominent for preventing stomal stenosis. ${ }^{[4,69,10]}$ But the data to support this empiric approach is still lacking in the literature.

There are multiple surgical techniques to overcome tracheal stenosis after total laryngectomy. ${ }^{[8-11]}$ One of this method was described by Kim et al. ${ }^{\left[{ }^{[1]}\right]}$ recently. Basically, there are two infrastomal incisions each $2 \mathrm{~cm}$ long which was made at 4 and $80^{\prime}$ clock direction from the stoma. After proper dissection of subcutaneous tissue and fat tissue removing vertical cuts made to 3 tracheal rings at 4 and 80 'clock direction. Skin flaps sutured to newly formed tracheal cut. This is highly effective and simple method to perform. All patients had significant increase in the diameter of the stoma in our study. None of the patients had need to use laryngeal tube after the surgery. There was no complication due to stomal surgery. All patients were discharged at postoperative day I without any problem. All patients had trouble-free follow up period. We always waited for stomal surgery at least for 6 months after total laryngectomy procedure. Because we wanted to observe maximal wound contractures through the stoma. So, we recommend waiting at least for 6 months after total laryngectomy for stenosis surgery. Most of the patients were reluctant to have any additional surgery after total laryngectomy. So, it may be wise to wait for their psychological recovery after total laryngectomy. Surgical team must encourage the patient and his/her relatives about the extent of the surgery. It should be noted that it is quite simple and effective method to increase their pulmonary capacity. Because most of the patients were afraid of having another comprehensive surgery like total laryngectomy. This technique leaves the superior tracheostomal junction intact. Because in most of the cases, the stenosis does not involve posterior membranous part of the trachea were the cartilage rings are missing. Furthermore, this is the place for voice prothesis insertion. So, this area should be kept intact. This is one of the superiorities of this technique. Another pitfall about the technique that during the dissection one should excise any granulation and fat tissue just the anterior to trachea. This will help both to tracheal mobilization and skin flap suturing without any tension.

Double reversing Z-plasty is an effective surgical method to manage tracheostomal stenosis developed after total laryngectomy. It decreases tension without disturbing the posterosuperior stomal junction where is the crucial for phonatory prosthesis.

\section{Ethics Committee Approval}

Approved by the local ethics committee (date: 29.04.2020 desicion number: 2020/5/4//76//2).

Informed Consent

Retrospective study.

Peer-review

Internally peer-reviewed.

Authorship Contributions

Concept: B.K.; Design: B.K.; Supervision: H.A.; Fundings: H.A.; Materials: B.K., H.A.; Data: B.K., H.A.; Analysis: H.A.; Literature search: B.K.; Writing: B.K.; Critical revison: H.A.

Conflict of Interest

None declared.

\section{REFERENCES}

1. Stell PM. The first laryngectomy. J Laryngol Otol 1975;89:353-8.

2. Bain JA. Late complications of tracheostomy and prolonged endotracheal intubation. Int Anesthesiol Clin 1972;10:225-44. [CrossRef]

3. Langenbrunner DJ, Chandler JR. Tracheal stomal stenosis: causes and correction. South Med J 1968;61:838-42. [CrossRef]

4. Yonkers AJ, Mercurio GA Jr. Tracheostomal stenosis following total laryngectomy. Otolaryngol Clin North Am 1983;16:391-405.

5. De Virgilio A, Greco A, Gallo A, Martellucci S, Conte M, de Vincentiis $\mathrm{M}$. Tracheostomal stenosis clinical risk factors in patients who have undergone total laryngectomy and adjuvant radiotherapy. Eur Arch Otorhinolaryngol 2013;270:3187-9. [CrossRef]

6. Wax MK, Touma BJ, Ramadan HH. Tracheostomal stenosis after laryngectomy: incidence and predisposing factors. Otolaryngol Head Neck Surg 1995;113:242-7. [CrossRef]

7. Kuo M, Ho CM, Wei WI, Lam KH. Tracheostomal stenosis after total laryngectomy: an analysis of predisposing clinical factors. Laryngoscope 1994;104:59-63. [CrossRef]

8. Trivedi NP, Patel D, Thankappan K, Iyer S, Kuriakose MA. Stomaplasty-anterior advancement flap and lateral splaying of trachea, a simple and effective technique. J Postgrad Med 2008;54:214. [CrossRef] 
9. Myers EN, Gallia LJ. Tracheostomal stenosis following total laryngectomy. Ann Otol Rhinol Laryngol 1982;91:450-3. [CrossRef]

10. Donegan JO, Silver F. Correction of tracheal stomal stenosis. Laryngoscope 1984;94:977-9. [CrossRef]

11. Kim YH, Kim NH, Seong SY, Hyun DW, Choi HS. Double revers- ing Z-plasty with inferiorly widening stomaplasty for the management of tracheostomal stenosis. Auris Nasus Larynx 2010;37:361-4.

12. Nigam A, Campbell JB, Dasgupta AR. Does the location of the laryngectomy stoma influence its ultimate size? Clin Otolaryngol Allied Sci 1993;18:193-5. [CrossRef]

\section{Trakeastomal Stenoz Gelişen Total Larenjektomi Olgularında Çift Ters Z Plasti}

Amaç: Total larenjektomi yapılan ve trakeastomal stenoz gelişen olgularda uygulanan çift terz $\mathrm{Z}$ plasti tekniğinin etkinliğini değerlendirmek.

Gereç ve Yöntem: Bu çalışma retrospektif bir dosya analizi idi. Kliniğimizde Ağustos 2016 ve Ekim 2019 yılları arasında total larenjektomi sonrası gelişen ve çift ters Z plasti cerrahisi uygulanmış 20 trakeal stenoz vakasının dosya kayıtları incelendi. Hastaların dosya tetkiklerinden ameliyat öncesi ve ameliyat sonrası I. ayda yapılan stoma çap ölçümleri çıkartıldı. Stoma çap ölçümleri mm olarak en geniş alınmış değer olarak dosyalarda mevcut idi. Ameliyat öncesi ve sonrası stoma çapları karşılaştıııldı.

Bulgular: Yirmi hastada da stoma çap genişliği istatiksel olarak artmış idi. Yirmi hastanın ameliyat öncesi en geniş stoma çap ölçümleri $12 \pm 1.2 \mathrm{~mm}$ (aralık 10-14) iken ameliyat sonrası bu ölçümler $21 \pm 1.3 \mathrm{~mm}$ (aralık 19-24) olarak tespit edildi ( $\mathrm{p}=0.01)$. On hastada (\%50) daha önce uygulanmış olan ses protezi mevcut idi. Bu hastalar ses protezlerini ameliyattan hemen sonra problemsiz olarak kullanmaya başladı. Tüm hastalar ameliyat sonrası I. günde sorunsuzca taburcu edildi. Ameliyat sonrası süreçte hiçbir hastamızda stoma darlığı için kanül kullanma ihtiyacı olmadı. Bu tüm hastalarımızda stoma cerrahisinin başarılı olduğunu göstergesi olarak kabul edildi.

Sonuç: Çift ters Z plasti tekniği, total larenjektomi sonrası gelişebilen trakeal stenoz olgularının cerrahi olarak düzeltilmesinde kullanılabilecek etkili bir yöntemdir.

Anahtar Sözcükler: Stomaplasti; total larenjektomi; trakeal stenoz. 